\title{
Land-use change influence soil quality parameters at an ecologically fragile area of YongDeng County of Gansu Province, China
}

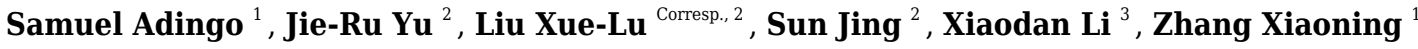 \\ ${ }^{1}$ College of Forestry, Gansu Agricultural University, Lanzhou, Gansu Province, China \\ 2 College of Resources and Environment, Gansu Agricultural University, Lanzhou, Gansu Province, China \\ 3 School of Management, Gansu Agricultural University, Lanzhou, Gansu Province, China \\ Corresponding Author: Liu Xue-Lu \\ Email address: liux|@gsau.edu.cn
}

Dry ecosystems, despite their relative levels of aridity, are very diverse, and play a vital role in the livelihoods of many dryland inhabitants. It is therefore critical to investigate the relationship between land-use change and soil quality parameters to offer a scientific basis for optimizing land-use planning and improving soil quality status in dry ecosystems and ecologically vulnerable areas. This study, therefore, analyzed the physicochemical properties of soils in five different land-use types namely farmland, abandoned farmland, natural grassland, artificial lemon forest, and poplar woodland at YongDeng County. The soil quality status of the aforementioned land-use types was also evaluated through Principal component analysis. The results revealed that abandoned farmland and natural grassland recorded the highest average values of soil coarse particles of $24.0 \%$ and 23.4 $\%$ respectively compared to the other land-use types. The highest average value $(46.1 \%)$ of fine soil particles was recorded in poplar woodland followed by natural grassland (36.6 $\%)$ and the average value of very fine soil particles was higher in farmland (40.8\%) and artificial lemon woodland (38.3 \%) than in the other land-use types. The average value of clayey particles was highest in farmland (11.1\%), followed by artificial lemon woodland (9.3\%), and abandoned farmland (6.5\%), then poplar woodland which recorded an average value of ( $4.2 \%)$. The average values of Soil water content, soil $\mathrm{pH}$, soil electrical conductivity, and soil total nitrogen content were significantly higher in farmland compared to the other land-use types. Soil organic carbon content was significantly higher in abandoned farmland at $(P<0.03)$ and lemon woodland at $(P<0.01)$ than in farmlands, natural grasslands, and poplar stands. The soil quality indicators of the different land-use types were significantly correlated with each other. Among them, the correlation coefficient of each evaluation index was highest in poplar woodland, followed by natural grassland, lower in farmland and artificial lemon woodland, and lowest in abandoned 
farmland. The overall soil quality scores were in the following order: farmland $>$ abandoned farmland $>0>$ grassland $>$ lemon woodland $>$ poplar woodland. In the study area, the soil quality of farmland that has been finely managed and naturally restored to grassland following abandonment is superior, whereas the soil quality of natural grassland, artificial lemon woodland, and poplar forest land is substandard. The comprehensive analysis of soil quality demonstrates that conservation tillage and fine management of water-irrigated farmland, as well as the natural conversion of abandoned farmland to grassland, can significantly improve the soil quality of sandy soils, reduce water and soil loss, increase fertility, and gradually improve regional ecological environmental conditions. 
1 Land-use Change Influence Soil Quality Parameters at

2 an Ecologically Fragile Area of YongDeng County of

3 Gansu Province, CHINA.

\author{
Samuel Adingo ${ }^{1}$, Jie-Ru Yu², Liu Xue-Lu ${ }^{2 *}$, Xiaodan $\mathrm{Li}^{3}$, Sun Jing ${ }^{2}$, Zhang Xiaong ${ }^{1}$
}

${ }^{1}$ College of Forestry, Gansu Agricultural University, Lanzhou, Gansu, China

${ }^{2}$ College of Resources and Environment, Gansu Agricultural University, Lanzhou, Gansu, China

${ }^{3}$ School of Management, Gansu Agricultural University, Lanzhou, Gansu, China

\title{
Corresponding Author:
}

Liu Xue-Lu

No.1 YingMen Road, Aning District, Lanzhou-Gansu Province, 730070, China.

Email address: liuxl@gsau.cn

\section{Abstract}

Dry ecosystems, despite their relative levels of aridity, are very diverse, and play a vital role in the livelihoods of many dryland inhabitants. Notwithstanding their importance, dry ecosystems are being degraded through a complex combination of climatic and human stresses, such as landuse change. It is therefore critical to investigate the relationship between land-use change and soil quality parameters to offer a scientific basis for optimizing land-use planning and improving soil quality status in dry ecosystems and ecologically vulnerable areas. Following this, this study analyzed the physicochemical properties of soils in five different land-use types namely farmland, abandoned farmland, natural grassland, artificial lemon forest, and poplar woodland at YongDeng County. The soil quality status of the aforementioned land-use types was also evaluated through Principal component analysis. The results revealed that abandoned farmland and natural grassland, recorded the highest average values of soil coarse particles of $24.0 \%$ and $23.4 \%$ respectively compared to the other land-use types. The highest average value (46.1\%) of fine soil particles was recorded in poplar woodland followed by natural grassland $(36.6 \%)$ and the average value of very fine soil particles was higher in farmland (40.8\%) and artificial lemon woodland (38.3\%) than in the other land-use types. The average value of clayey particles was highest in farmland (11.1\%), followed by artificial lemon woodland $(9.3 \%)$, and abandoned farmland (6.5\%), than poplar woodland that recorded an average value of $(4.2 \%)$. The average values of Soil water content, soil $\mathrm{pH}$, soil electrical conductivity, and soil total nitrogen content were significantly higher in farmland compared to the other land-use types. Soil organic carbon content was significantly higher in abandoned farmland at $(P<0.03)$ and lemon woodland at $(P<0.01)$ than in farmlands, natural grasslands, and poplar stands. The soil quality indicators of the different land-use types were significantly correlated with each other. Among them, the correlation coefficient of each evaluation index was highest in poplar woodland, followed by 
40 natural grassland, lower in farmland and artificial lemon woodland, and lowest in abandoned

41 farmland. The overall soil quality scores were in the following order: farmland $>$ abandoned

42 farmland $>0>$ grassland $>$ lemon woodland $>$ poplar woodland. In the study area, the soil

43 quality of farmland that has been finely managed and naturally restored to grassland following

44 abandonment is superior, whereas the soil quality of natural grassland, artificial lemon

45 woodland, and poplar forest land is substandard. The study revealed that land-use change has a

46 significant effect on the quality and spatial distribution of soil physicochemical properties. The

47 comprehensive analysis of soil quality demonstrates that conservation tillage and fine

48 management of water-irrigated farmland, as well as the natural conversion of abandoned

49 farmland to grassland, can significantly improve the soil quality of sandy soils, reduce water and

50 soil loss, increase fertility, and gradually improve regional ecological environmental conditions.

51

\section{Introduction}

53 Soil is a balance of physical, chemical, and biological processes in nature, and is also an 54 independent historical natural body (Manpoong and Tripathi, 2019). The quality of soil is 55 directly or indirectly related to the food quality of people (and animals), the quality of the living environment, the health status, and the well-being of the breeding offspring (E. Jobbágy and R.

58

59

60

61

62

63

64

65

66

67

68

69

70

71

72

73

74

75

76

77

78

79 Jackson, 2000). Over the past years, there have been concerted efforts by relevant stakeholders to achieve the goal of sustainable agriculture to feed the ever-growing population of the world, which is estimated to reach 9 billion by the year 2050 (Kyte, 2014; Lammerts van Bueren et al., 2018; Yang et al., 2019; Sahu et al., 2020). However, attaining sustainable agriculture remains a mirage as it has been greeted with challenges such as climate change (Calicioglu et al., 2019) which has resulted in unreliable and irregular rainfall patterns, pests and diseases, and loss of important soil resources due to soil erosion (Ding et al., 2013).

The aim of land use, land management, climatic conditions, and intrinsic soil qualities all influence changes in soil parameters (Yan Zhang et al., 2018). Soil deterioration can be caused by the use of land for cultivation or development, as well as the removal of natural vegetation and disruption of the soil profile (Shekhovtseva \& Mal'tseva, 2015). Converting native vegetation to farmland lowers soil nutrient and the content of soil organic carbon and at the same time, increase bulk density (Zucca et al., 2010) and sand content (Biro et al., 2013). In addition, the genetic soil layer is highly altered in urban areas, resulting in soil constriction and loss of soil organic carbon (SOC) (Zambon et al., 2018). Urban soils, on the other hand, are regarded as carbon sinks (Weissert et al., 2016). Long-term irrigation, for example, can enhance soil carbon and nitrogen content while also improving soil quality (Fiorini et al., 2020). Agricultural wastes can also help with carbon and nitrogen sequestration in the soil (Deng et al., 2016). Nevertheless, in arid areas, changes in soil organic carbon and nutrient content resulting from cropland abandonment are largely determined by soil and climatic conditions (Kosmas, Gerontidis and Marathianou, 2000). (Evans and Belnap, 1999) showed that arid ecosystems experience a loss of soil nutrients due to land-use change. As a result, soil quality deteriorates, and soils become ecologically vulnerable, leading to soil degradation (Lal, 2015) and the 
80 weakening of erosion resistance (Khalili Moghadam et al., 2015). (Jeong and Dorn, 2019)

81 observed that in an area with a desert climate, land-use changes associated with urbanization

82 accelerate soil erosion. Land-use changes (e.g., from a forest or natural grassland to cropland and

83 pasture) on soil carbon and other nutrients is well documented (Smith et al., 2016). Moreover,

84 studies have mostly focused on the characteristics of urban pollution following land-use change

85 and associated soil properties such as SOC, $\mathrm{pH}$, and soil $\mathrm{N}$ (Yang et al., 2015). However, cities

86 are considered to be highly disturbed ecosystems and in arid regions, the response of soil

87 properties to these extreme disturbances is still unknown. To understand the dramatic changes in

88 land use and their impacts on ecosystems, further research is needed to explore the extent to

89 which changes in land use affect soil properties in arid environments. A better understanding of

90 these impacts is essential to optimize land use and soil conservation and minimize land

91 degradation, especially in fragile ecosystems.

92 YongDeng County in China's Gansu Province has experienced significant expansion, progress,

93 and development in areas such as agriculture and construction. The county's growth, production,

94 and expansion in various industries have led to a rapid increase in land use. Due to its special

95 ecological characteristics, natural geographic location, and recent land degradation, the state has

96 taken measures such as returning farmland to forest and grass and grassland sealing to improve

97 the ecological environment, reduce the degree of desertification, and facilitate the recovery of

98 vegetation. At present, there are mainly five types of land use in the area: farmland, abandoned

99 farmland, natural grassland, lemon woodland, and poplar woodland. In this study, we seek to

100 investigate the distribution of surface vegetation and determine the physical and chemical

101 characteristics of soil in the different land-use types in the area and also use principal component

102 analysis to comprehensively evaluate the soil quality status of the aforementioned land-use types,

103 aiming to elucidate the influence of land-use change on soil quality and to provide a basis for

104 "returning farmland to forests and grasslands" and adopting reasonable land-use policies in the

105 area.

106

\section{Materials \& Methods}

108 Research Area Overview

109 The location of the research area is depicted in Figure 1. It is located between the latitudes of

$110102^{\circ} 36^{\prime}$ and $103^{\circ} 45^{\prime}$ East and $36^{\circ} 12^{\prime}$ and $37^{\circ} 07^{\prime}$ North. It has a typical continental monsoon

111 climate of the mid-temperate range. Annual rainfall is estimated to range between 30 and 600

$112 \mathrm{~mm}$, with a steadily decreasing southeast-to-northwest gradient, with summer accounting for

11358.8 percent of total precipitation, and significant inter-annual variability of precipitation.

114 Evapotranspiration is $2710 \mathrm{~mm}$ per year, and the frost-free period is 120 days per year. The

115 annual average temperature is $7.7 \mathrm{C}$, and the climate varies significantly between winter and

116 summer, with an average temperature difference of $28 \mathrm{C}$. The average annual wind speed is 2.8

$117 \mathrm{~ms}^{-1}$, and winter and spring bring plenty of sandy weather, with 323 sand rise greater than $5 \mathrm{~ms}^{-1}$

118 per year. 
119 The topography of the area is naturally hilly, with stony mountains and loess hills. The cliffs are

120

121

122

123

124

125

126

127

128

129

130

131

132

133

134

135

136

137

138

139

140

141

142

143

144

145

146

147

148

149

150

151

152

153

154

155

156

157

158

interconnected, while the plains are undulating, with the Yellow River running through them.

Within YongDeng County's elevation range of 1000-3000 meters are the Loess highlands, Inner Mongolia, and the Qinghai-Tibet plateau. The region's zoned soils are primarily yellow cotton soil, gray calcium soil, and light gray calcium soil; the region's non-zoned soils are primarily sandy soil, saline soil, and meadow soil, among others, with sandy soil being particularly prevalent in the region's north-central part. The soil texture is a predominantly light loam, sandy loam, and sandy soil, all of which have a loose structure and low fertility. The soil type used in this study is pedocals (calcareous) which are neutral to alkaline in reaction.

The study site included five distinct land uses: farmland (F), abandoned farmland (Q), natural grassland $(\mathrm{G})$, artificial lemon woodland $(\mathrm{N})$, and poplar woodland $(\mathrm{Y})$. Maize (Zea mays) is the predominant crop planted by farmers in this study area, with an average height of $2.52 \mathrm{~m}$, row spacing of $75 \mathrm{~cm}$, plant spacing of $25 \mathrm{~cm}$, and an area of $11.8 \mathrm{hm}^{2}$. Simultaneously, artificially planted lemon and poplar trees are frequently used to promote vegetation restoration in severely degraded areas, preventing wind erosion and aiding in sand fixation, and enhancing the soil environment. The average canopy width of an artificial lemon tree is $0.42 \mathrm{~m}^{2}$, the average plant density is 0.52 plants per $\mathrm{m}^{2}$, and covers an area of $15.3 \mathrm{hm}^{2}$, with plants spaced $7 \mathrm{~m}$ apart and rows spaced between 5 and $8 \mathrm{~m}$ apart. The average height of an artificially planted poplar tree is $4.5 \mathrm{~m}$, with a diameter of $9 \mathrm{~cm}$ at breast height, a row spacing of $8-10 \mathrm{~m}$, and a surface area of $14.0 \mathrm{hm}^{2}$. Natural grassland in the study area occupies approximately 13.3 hectares. Artemisia scoparia, Pennisetum centrasiaticum, and Lespedeza potaninii dominate the surface vegetation in this area as shown in (Table 1).

\section{Experimental design}

In the summer of 2020 (end of July), five different land-use types were chosen as study plots in the study area: farmland (maize field), abandoned farmland, natural grassland, artificial lemon woodland land, and poplar woodland land. Within each study plot, four (4) soil sampling sites were located at the two diagonal corners and the center of the plot. Soils at each sampling site were collected from soil depth of $0-10 \mathrm{~cm}$ using a $5 \mathrm{~cm}$ diameter soil auger with three replicates each, which were homogenized by hand mixing thoroughly to obtain composite sample (each sample was not less than $1 \mathrm{~kg}$ ). Samples were placed in well-labeled plastic bags and transported immediately to the laboratory. A total of sixty (60) soil samples ( 5 types of sample plots $\times 4$ sampling points $\times 3$ replicate samples) were collected in all the study plots. In abandoned farmland, natural grassland, artificial lemon woodland, and poplar woodland, one herbaceous survey sampling Quadrat with an area of $1 \times 1 \mathrm{~m}^{2}$ was set up and random sampling method used to survey the surface herbaceous vegetation, to determine the number of individuals $\left(\right.$ plant $\cdot \mathrm{m}^{-2}$ ), abundance, and height $(\mathrm{cm})$ as the background of the sample plots (Table 1). This was repeated three times in the respective study plot with an interval of more than $15 \mathrm{~m}$ between sampled points.

Peer] reviewing PDF | (2021:07:63271:1:2:NEW 6 Sep 2021) 
159 Soil sample collection and soil parameters determination

160 Surface mixed soil samples $(0-10 \mathrm{~cm})$ were taken at each survey sample site for soil index

161 determination. First, 1/4 of the fresh soil samples collected were used for soil moisture content

162 determination. Then, the remaining $3 / 4$ of the soil samples were passed through a $2 \mathrm{~mm}$ soil

163 sieve to remove impurities such as plant roots and foreign material such as dead plant parts, old

164 manure, gravels, and compost to reduce variation which may occur as a result of dilution of

165 organic matter due to mixing through cultivation and other factors. Samples were then air-dried

166 in a natural state and then used to determine soil particle size composition, $\mathrm{pH}$, electrical

167 conductivity, organic carbon and total nitrogen content.

168 Soil moisture content (\%) was determined by the drying method, in which an aluminum box 169 containing fresh soil samples was weighed on an analytical balance to the nearest $0.01 \mathrm{~g}$. The

170 samples were then placed in an oven at $105^{\circ} \mathrm{C}$ for 24 hours and weighed immediately after

171 cooling to room temperature. Soil particle size composition was determined using a Mastersizer

1723000 laser diffraction particle size analyzer (Malvern, Uk-LD_3000) using an array of 52

173 detectors with a repeatability error $\leq \pm 0.5 \%$, and an accuracy error $\leq \pm 1 \%$. Soil texture was

174 classified according to the United States Department of Agriculture (USDA) soil texture

175 classification criteria: coarse soil particles $(250-1000 \mu \mathrm{m})$, fine soil particles $(100-250 \mu \mathrm{m})$, very

176 fine soil particles $(50-100 \mu \mathrm{m})$, clay particles $(<50) \mu \mathrm{m})$ (Shangguan et al., 2014). Soil pH value

177 (water-soil ratio suspension ratio of 2.5:1), soil electrical conductivity $\left(\mu \mathrm{s} \cdot \mathrm{m}^{-1}\right)(5: 1$ for water-

178 soil ratio leachate) were determined with a $\mathrm{P} 4$ multifunctional measuring instrument. Soil

179 organic carbon $\left(\mathrm{g} \cdot \mathrm{kg}^{-1}\right)$ was determined by the potassium dichromate external heating method,

180 and soil total nitrogen $\left(\mathrm{g} \cdot \mathrm{kg}^{-1}\right)$ was determined by the semi-micro Kjeldahl method (Sáez-Plaza

181 et al., 2013).

182

183 Soil Quality Evaluation Method

184 Selection of evaluation indicators

185 This paper selected and established a comprehensive evaluation index system appropriate for this

186 study based on the research on soil quality evaluation systems by (Cao et al., 2021). Nine distinct

187 indicators were selected including coarse soil particles $\left(\mathrm{X}_{1}\right)$, fine soil particles $\left(\mathrm{X}_{2}\right)$, very fine soil

188 particles $\left(\mathrm{X}_{3}\right)$, clay soil particles $\left(\mathrm{X}_{4}\right)$, soil water content $\left(\mathrm{X}_{5}\right)$, soil $\mathrm{pH}$ value $\left(\mathrm{X}_{6}\right)$, soil electrical

189 conductivity $\left(\mathrm{X}_{7}\right)$, soil organic carbon $\left(\mathrm{X}_{8}\right)$, and soil total nitrogen $\left(\mathrm{X}_{9}\right)$.

190 Principal component analysis steps followed in this work are as follows:

191 (1) the original data matrix X, which includes the aforementioned nine soil indicators were

192 enumerated.

193 (2) Standardization of raw data. Because each index has a different magnitude, the raw data for

194 each measured index was standardized to eliminate the effect of different magnitude on the

195 evaluation results (Vidal, Ma and Sastry, 2016). The standardization formula is as follows;

196

197

$$
X_{i j}=\frac{x_{i j}-\bar{x}_{j}}{S_{j}}
$$


198

199

200

201

202

203

204

205

206

207

208

209

210

211

212

213

214

215

216

217

218

219

220

221

222

223

224

225

226

227

228

229

230

231

232

233

234

235

236

Where $X_{i j}$ is the standardized value of the $j$ th indicator of the $i$-th sample plot; $X_{\mathrm{ij}}$ is the measured value of the $j$ th indicator of the $i$-th sample plot; $X_{i j}$ is the average value of the $j$ th index; $S_{j}$ is the standard deviation of the $j$ th indicator; $i$ is the number of sample plots $(i=1,2,3,4,5$ in this paper); $j$ is the number of indicators selected in the evaluation $(j=1,2, \ldots .9$ in this article).

(3) The sample's correlation matrix R was calculated.

(4) Jacobi's method was used to evaluate the eigenvalues and eigenvectors of the correlation matrix R (Demmel and Veselić, 1992).

(5) The contribution rate and cumulative contribution rate, as well as the number of principal components, their meanings, were determined and principal component equations established.

(6) The factor loading of each principal component and the indicator's common factor variance were calculated. Each indicator's weight $w_{j}$ was calculated using the equation below;

$$
\sum_{j-1}^{n} w_{j}=1
$$

(7) The comprehensive evaluation value of soil quality for each land-use type was calculated based on the weight of each index, and the soil quality of different land-use types was evaluated accordingly. The comprehensive evaluation values of soil quality for different land-use types were determined by the equation;

$$
P i=\sum_{j-1}^{n} X_{i j} w_{j}
$$

Where $P i$ is the comprehensive evaluation value of soil quality of the $i$-th land-use type; $X i j$ is the standardized value of the $j$ th indicator of the $i$-th land-use type; $w j$ is the weight value of the $j$ th indicator, obtained by principal component analysis; $i$ is the number of sample sites $(i=1,2,3$, 4, 5 in this paper); $n$ is the number of indicators selected in the evaluation ( $n=9$ in this paper).

\section{Data processing and analysis}

All data were statistically analyzed using SPSS20.0 software. One-way analysis of variance (One-Way ANOVA) and least significant differences (LSD) method was used to analyze the differences between different data groups, and Spearman's correlation coefficient was used to analyze the correlation between different indicators. The significance level was $(P=0.05)$

\section{Results}

\section{Impact of land use change on Soil physical and chemical properties Soil particle size composition}

As shown in (Table 2), there were significant differences $(P<0.05)$ in soil particle composition among different land-use types. Among them, abandoned farmland and natural grassland, recorded the highest average values of soil coarse particles of $24 \%$ and $23 \%$ respectively and 
237

238

239

240

241

242

243

244

245

246

247

248

249

250

251

252

253

254

255

256

257

258

259

260

261

262

263

264

265

266

267

268

269

270

271

272

273

274

275

276

were significantly higher than farmland, artificial lemon woodland, and poplar woodland which recorded average values of $18 \%, 18 \%$ and $16 \%$ respectively, but there was no significant difference $(P>0.05)$ between farmland and artificial lemon woodland. The highest average value (46\%) of fine soil particles was recorded in poplar woodland followed by natural grassland (3 $\%$ ) whiles farmland, abandoned farmland and artificial lemon woodland recorded fine soil particles content values of $28 \%, 35 \%$ and $33 \%$ respectively. The average value of very fine soil particles was higher in farmland (40\%) and artificial lemon woodland (38\%) than in abandoned farmland (33\%), natural grassland (32\%), and poplar woodland (32\%). The average value of clayey particles was significantly higher in farmland (11\%), artificial lemon woodland (9\%), and abandoned farmland (6\%), than poplar woodland, which recorded an average value of (4 $\%)$.

\section{Soil moisture}

As illustrated in (Figure 2), there was a significant difference $(P<0.05)$ between the soil moisture contents among the land-use types. The highest average value (4\%) of soil water content was found in farmland, compared to abandoned farmland, natural grassland, artificial lemon woodland and poplar woodland, which recorded average soil water content values of $1 \%, 0.9 \%$, $0.7 \%$ and $0.8 \%$ respectively. The soil water content of abandoned farmland was significantly higher than that of artificial lemon woodland and poplar forest land $(P<0.03)$, while natural grassland was in between. There were no significant differences $(P>0.06)$ between natural grassland and the abandoned farmland, and between natural grassland and artificial lemon woodland and poplar woodland.

\section{Soil pH and electrical conductivity}

From (Figure 3), it can be seen that the soils in this area are weakly alkaline, and there were significant differences $(P<0.05)$ among different land-use types. The soil $\mathrm{pH}$ value was highest in farmland (8) and was significantly higher than abandoned farmland, natural grassland, artificial lemon woodland, and poplar woodland $(P<0.03)$, and abandoned farmland and natural grassland recorded soil $\mathrm{pH}$ values of 7 and 7 respectively which were significantly higher than artificial lemon woodland and poplar woodland $(P<0.05)$ but there was no significant difference between abandoned farmland and grassland and between artificial lemon woodland and poplar forest land $(P>0.05)$. As shown in (Figure 4), the soil electrical conductivity of farmland was significantly higher than that of abandoned farmland, natural grassland, artificial lemon woodland, and poplar woodland $(P<0.04)$, but there was no significant difference between the latter four $(P>0.07)$.

\section{Soil organic carbon and total nitrogen}

As shown in (Figure 5), there was a significant difference $(P<0.05)$ in soil organic carbon among different land-use types. The highest soil organic carbon $\left(5 . \mathrm{g} . \mathrm{kg}^{-1}\right)$ was found in abandoned farmland which was significantly higher at $(P<0.04)$ than that of farmland, natural grassland, 
277 lemon woodland, and poplar woodland which recorded soil organic carbon values of 4 g.kg-1 3

278 g.kg ${ }^{-1}, 4$ g. $\mathrm{kg}^{-1}$ and 2 g. $\mathrm{kg}^{-1}$ respectively. There was no significant difference in the soil organic 279 carbon content of farmland, and lemon woodland $(P>0.07)$ but they were significantly higher 280 than the poplar woodland $(P<0.02)$.

281 As can be seen from (Figure 6), the total $\mathrm{N}$ of the soil was significantly higher $(P<0.04)$ in 282 farmland which recorded a total $\mathrm{N}$ average value of $0.6 \mathrm{~g}^{\mathrm{kg}} \mathrm{kg}^{-1}$ than in abandoned farmland, 283 natural grassland, lemon woodland, and poplar woodland which recorded average values of 0.5 284 g. $\mathrm{kg}^{-1}, 0.3 \mathrm{~g} \cdot \mathrm{kg}^{-1}, 0.4 \mathrm{~g} . \mathrm{kg}^{-1}$ and $0.2 \mathrm{~g} . \mathrm{kg}^{-1}$ respectively. The average total $\mathrm{N}$ value of abandoned 285 farmland was significantly higher $(P<0.03)$ than that of natural grassland, lemon woodland, and 286 poplar woodland. The average value of total $\mathrm{N}$ of artificial lemon woodland was significantly 287 higher than that of poplar forest land $(P<0.04)$, but there was no significant difference between 288 artificial lemon woodland and natural grassland $(P>0.06)$.

289

290

291

292

293

294

295

296

297

298

299

300

301

302

303

304

305

306

307

308

309

310

311

312 Comprehensive evaluation of soil quality

313 As shown in (Table 4), the first three principal components were extracted using the eigenvalue

$314 \lambda>1$ principle, with eigenvalues of 5,2 , and 1 , respectively, and variance contribution rates of 55

315 percent, 18 percent, and 13 percent, respectively. In addition to satisfying the fundamental

316

\section{Correlation analysis between soil quality indicators of different land- use types}

As can be seen from (Table 3), in farmland, coarse soil particles were negatively correlated (0.991) with very fine soil particles; fine soil particles were negatively correlated $(-0.901)$ with clay soil particles; very fine soil particles were negatively correlated $(-0.905)$ with soil water content; soil water content was positively correlated $(0.913)$ with soil total nitrogen. There was no correlation among all indicators in abandoned farmland. In natural grassland, coarse soil particles were negatively correlated $(-0.893)$ with very fine soil particles, and positively correlated $\left(0.927^{*}\right)$ with soil organic carbon; soil water content was negatively correlated ($0.902)$ with soil electrical conductivity and soil total nitrogen (-0.993); Soil electrical conductivity was positively correlated (0.920) with total soil nitrogen. In artificial lemon woodland, coarse soil particles were negatively correlated (-0.912) with fine soil particles and very fine soil particles (-0.94); soil water content was positively correlated $(0.895)$ with soil electrical conductivity. In poplar woodland, coarse soil particles were negatively correlated with very fine soil particles (-0.942), soil total nitrogen $(-0.942)$, and soil organic carbon $(-0.907)$; fine soil particles were significantly negatively correlated $(-0.039)$ with soil total nitrogen $(P<0.01)$; clay soil particles were positively correlated $\left(0.948^{*}\right)$ with soil total nitrogen and soil organic carbon $(0.932 *)$; soil total nitrogen was significantly positively correlated $\left(0.959^{* *}\right)$ with soil organic carbon. The comprehensive analysis shows that the correlation coefficient among the evaluation indexes was highest in poplar woodland, followed by natural grassland, lower in farmland and lemon woodland, and lowest in abandoned farmland.

condition that the eigenvalue should be greater than $1(\lambda>1)$, the condition that the cumulative

Peer) reviewing PDF | (2021:07:63271:1:2:NEW 6 Sep 2021) 
317 contribution of the first $n$ principal components is at least 85 percent must also be satisfied. Only 318 when both conditions are satisfied can the first $n$ principal components be considered to have 319 effectively reflected the information of the original variable. The cumulative contribution of the 320 first three principal components in this study was 87 percent (>85 percent), implying that the first

321

322

323

324

325

326

327

328

329

330

331

332

333

334

335

336

337

338

339

340

341

342

343

344

345

346

347

348

349

350

351

352

353

354

355

356 three principal components can represent all the information. The first principal component combined data from seven evaluation indicators with coefficients greater than 0.5 , including fine soil particles $\left(\mathrm{X}_{2}\right)$, very fine soil particles $\left(\mathrm{X}_{3}\right)$, soil clay particles $\left(\mathrm{X}_{4}\right)$, soil water content $\left(\mathrm{X}_{5}\right)$, soil $\mathrm{pH}$ value $\left(\mathrm{X}_{6}\right)$, soil electrical conductivity $\left(\mathrm{X}_{7}\right)$, and soil total nitrogen $\left(\mathrm{X}_{9}\right)$. The first principal component had the highest contribution rate and contained the most indicators, indicating that these soil indicators are critical for soil quality and can be used to explain 55 percent of the original nine soil quality factors. The second major component consisted of two indicators, soil coarse sand $\left(\mathrm{X}_{1}\right)$ and very fine soil particles $\left(\mathrm{X}_{3}\right)$, both of which had coefficients greater than 0.5 and accounted for 18 percent of the original soil's quality. The third principal component consisted of two indicators: soil $\mathrm{pH}\left(\mathrm{X}_{6}\right)$ and soil organic carbon $\left(\mathrm{X}_{8}\right)$, which together accounted for 13 percent of the original soil's overall quality. The principal component score equation was established as follows using the principal component score matrix:

$$
Z_{I}=0.009 \mathrm{X}_{1}-0.171 \mathrm{X}_{2}+0.136 \mathrm{X}_{3}+0.171 \mathrm{X}_{4}+0.177 \mathrm{X}_{5}+0.135 \mathrm{X}_{6}+0.178 \mathrm{X}_{7}+0.099 \mathrm{X}_{8}+0.176 \mathrm{X}_{9}
$$

$Z_{2}=0.564 \mathrm{X}_{1}-0.116 \mathrm{X}_{2}-0.39 \mathrm{X}_{3}-0.145 \mathrm{X}_{4}+0.03 \mathrm{X}_{5}+0.091 \mathrm{X}_{6}-0.027 \mathrm{X}_{7}+0.201 \mathrm{X}_{8}+0.174 \mathrm{X}_{9}$

$Z_{3}=0.027 \mathrm{X}_{1}+0.196 \mathrm{X}_{2}-0.169 \mathrm{X}_{3}-0.207 \mathrm{X}_{4}+0.299 \mathrm{X}_{5}+0.47 \mathrm{X}_{6}+0.281 \mathrm{X}_{7}-0.58 \mathrm{X}_{8}-0.095 \mathrm{X}_{9}$

where $Z_{1}, Z_{2}, Z_{3}$ represent the three principal components, and $X_{1}-X_{9}$ represent the standardized variables of each evaluation index.

The standardized variables were incorporated into these three functional equations to obtain the soil scores $\mathrm{Z}$ for various land-use types. The variance contribution rate of the factors was used as the weight for the comprehensive evaluation, and the soil quality score for each land-use type was calculated by weighing the respective variance contribution rate. The comprehensive score of soil quality was obtained using the formula;

$$
\mathrm{F}=0.559 Z_{1}+0.190 Z_{2}+0.132 Z_{3}
$$

As shown in (Table 5), farmland, abandoned farmland, natural grassland, lemon woodland, and poplar woodland all had comprehensive soil quality scores of 1.017, 0.102, $-0.112,-0.336$, and 0.671 , respectively. Farmland had the highest comprehensive soil quality score, and only farmland and abandoned farmland had a positive comprehensive soil quality score, indicating that the soil quality of these two types of land use was above average, whereas the soil quality comprehensive scores of natural grassland, lemon woodland, and poplar forest land, were all negative and below average. 


\section{Discussion}

359 The impact of land-use change on the physical and chemical properties of soil

360 Human activities and climate change have resulted in dramatic changes in land use, surface

361

362

363

364

365

366

367

368

369

370

371

372

373

374

375

376

377

378

379

380

381

382

383

384

385

386

387

388

389

390

391

392

393

394

395

396 morphology, physical and chemical cycles, and ecological balance in recent years, resulting in significant changes in the global climate and irreversible species decline. Because land use has a significant impact on the environment's sustainable development, it has become one of the primary drivers of global environmental change (Statuto, Cillis and Picuno, 2016), while also having a significant impact on the physical and chemical properties of soil to a degree.

The composition of soil particle size is critical in determining soil anti-erodibility (Chen et al., 2013), and various land-use practices reflect disturbance-induced changes in soil particle size distribution (Feng et al., 2016). In this study, the coarse soil content of the soil ranged from high to low as follows: natural grassland $>$ abandoned farmland $>$ farmland $>$ lemon woodland $>$ poplar woodland; the fine soil particles content of the soil ranged from high to low as follows: poplar woodland $>$ natural grassland $>$ abandoned farmland $>$ lemon woodland $>$ farmland, and the very fine sand content of the soil ranged from high to low as follows: farmland $>$ lemon woodland $>$ farmland. The primary reason is that the crops cultivated in the area is maize, which had grown to a certain height and was densely planted at the time of sampling, and the surface vegetation cover of abandoned farmland, natural grassland, and lemon woodland was relatively high, which can reduce wind speed near the surface, reduce wind erosion, fix clay soil particles on the surface, and block clay particles from being blown away by the wind. Farmland contained the most clayey soil particles, which may be due to the artificial application of organic fertilizers by farmers in the study area. However, due to drought and low rainfall in poplar forests, tree body growth is poor and the ground surface lacks effective coverage, resulting in severe wind erosion, which blows away soil particles and increases fine sand content.

Farmland had a higher soil water content, high $\mathrm{pH}$ value, and electrical conductivity than abandoned farmland, natural grassland, lemon woodland, and poplar woodland in this study. The reasons for this are as follows: the vegetation roots of abandoned farmland, natural grassland, lemon woodland, and poplar forest land fiercely compete for soil moisture, resulting in a lack of water in the topsoil and low water content, whereas farmland in the study area has been artificially irrigated for an extended period, resulting in a much higher surface water content (Zhang et al., 2019; Yao et al., 2020). Because the soil in this area has been salinized, the overall $\mathrm{pH}$ value is high and alkaline. Among them, abandoned farmland, natural grassland, and lemon woodland are less disturbed by humans, have a high cover of surface vegetation, low evaporation, which protects the soil from erosion, and low salinity, which results in a lower soil $\mathrm{pH}$ and electrical conductivity (Koetlisi and Muchaonyerwa, 2019).

Soil organic carbon and total nitrogen are important indicators of soil fertility because they are derived primarily from above- and below-ground plant litter decomposition and are heavily influenced by vegetation, climate, and anthropogenic activities (Letters et al., 2019; Yu et al., 2020). The order of the soil organic carbon content in this study was farmland $>$ abandoned 
397

398

399

400

401

402

403

404

405

406

407

408

409

410

411

412

413

414

415

416

417

418

419

420

421

422

423

424

425

426

427

428

429

430

431

432

433

434

435

436

farmland $>$ lemon woodland $>$ farmland $>$ natural grassland $>$ Poplar woodland, and the order of the soil total nitrogen content was farmland $>$ abandoned farmland $>$ lemon woodland $>$ natural Grassland $>$ Poplar forest land. The soil organic carbon and total nitrogen contents of poplar forest land were the lowest because the majority of poplar forest land in this area has been planted as farmland protection forests, and the drought and low rainfall have caused them to grow poorly, with some dying, leaving the top layer soil highly susceptible to erosion and degradation. Farmland had a higher total nitrogen content than abandoned farmland, grassland, lemon woodland, and poplar woodland because farmland in this area is carefully managed to restore the soil's original fertility through fertilization, irrigation, and crop growth. However, tilling and reclamation of farmland's surface soil promotes soil respiration and accelerates carbon element decomposition, or because a significant amount of above-ground or underground farmland is removed during crop harvesting, and the proportion of carbon elements fixed by primary production allocated to the soil is low, reducing the organic carbon content (Kumar et al., 2017). The higher soil organic carbon and total nitrogen contents of abandoned farmland, natural grassland, and lemon woodland are a result of their high vegetation cover, which effectively prevents erosion and promotes organic matter accumulation (Batjes, 2014; Gerschlauer et al., 2019).

\section{Correlation between soil quality indicators under conditions of land-use change}

The interdependence of land quality indicators varies according to land-use type. The interaction and coordination effects between soil quality indicators can provide a comprehensive picture of the soil's productivity and adaptability to adversity (Paz-Ferreiro and $\mathrm{Fu}, 2016$ ).

To begin with, the composition of soil particle size has a significant effect on the structure and properties of the soil, affecting water absorption, anion and cation exchange, and the supply of nutrient elements such as carbon and nitrogen. There was a negative correlation between very fine soil particles and soil moisture content in farmland in this study, which is likely due to the higher content of very fine particles in farmland compared to abandoned farmland, natural grassland, lemon woodland, and poplar forest land, all of which increase water infiltration and decrease surface water content (Yost and Hartemink, 2019). There was a significantly negative correlation between soil coarse particles, soil organic carbon, and soil total nitrogen in poplar forest land, but a significantly positive correlation between very fine soil particles, soil clay particles, and soil organic carbon in poplar forest land. This is because clay particles in soil are the primary inorganic colloids, are cemented with organic matter, and provide a cementing environment as well as potentially acting as a protective factor for the soil's structural properties (Latifi et al., 2018). However, there was a positive correlation between soil coarse particles and soil total nitrogen in the natural grassland, which may be explained by the error introduced by fewer experimental replications in this study.

Secondly, the amount of water in the soil has a direct effect on the dissolution of various salts, material transformation, and decomposition of organic matter in the soil (Lu et al., 2011;

Fornara, Tilman and Houlton, 2012). The soil water content and electrical conductivity of lemon

Peer] reviewing PDF | (2021:07:63271:1:2:NEW 6 Sep 2021) 
437 woodland were positively correlated in this study, owing to the complete dissolution of various 438 salts in the soil, whereas the soil water content and electrical conductivity of natural grassland, 439 farmland, abandoned farmland, and poplar forest land was negatively correlated or even 440 uncorrelated. Additionally, the negative correlation between soil water content and soil organic

441

442

443

444

445

446

447

448

449

450

451

452

453

454

455

456

457

458

459

460

461

462

463

464

465

466

467

468

469

470

471

472

473

474

475

476 carbon content in natural grassland is because soil salinization impairs soil nutrient cycling, resulting in a decline in soil fertility and thus a decrease in soil organic carbon content (Herbert et al., 2015). By contrast, the soil water content of farmland was high due to anthropogenic irrigation, and the soil's relatively low salt content, which does not correlate with soil electrical conductivity. However, a certain amount of soil water facilitates the preservation of soil structure, which increases soil sorption, and increases nutrient uptake and soil solidity. The soil's adsorption capacity increases nutrient absorption and stability, thereby increasing the soil's organic carbon content (Amer, 2019).

Thirdly, a positive correlation existed between soil electrical conductivity and total soil nitrogen, which could be explained by an increase in soil electrical conductivity and an increase in the rate of organic matter accumulation and mineralization by the soil (Ding et al., 2020). This correlation was strongest in natural grasslands, but not in farmland, lemon woodlands, or poplar woodlands, most likely because natural grasslands have more surface vegetation and deadfalls, which are a major source of organic matter and total nitrogen in the soil.

Fourthly, soil organic carbon and total nitrogen content are important indicators of soil fertility and productivity, and changes in soil organic carbon and total nitrogen content are strongly influenced by land use and soil management (Negasa, 2020; Zhang et al., 2020). While there was a significant positive correlation between soil organic carbon and soil total nitrogen in poplar forest land, no correlation was observed in the other sample plots. The reason for this may be due to the effect of various land-use management factors on nitrogen mineralization in soil, clay mineral fixation, nitrification, and denitrification processes, as well as leaching via gaseous and post-solubilization, nitrogen fixation by plants, and competitive nitrogen utilization by plants and microorganisms. On the one hand, it demonstrates that soil organic carbon and total nitrogen enrichment in farmland, abandoned farmland, natural grassland, and lemon woodland are dynamic processes, as topsoil organic carbon and total nitrogen are more susceptible to disturbance by factors such as stand type, climatic environment, apoplankton abundance, and degree of decomposition (Zhang et al., 2021). For example, tillage activities, abandoned farmland and natural grassland restoration processes, as well as the evolution of lemon woodland, all have a profound effect on the relationship between soil organic carbon and total nitrogen in the soil. Simultaneously, the sparse herbaceous vegetation covers in the understory of the poplar woodland, the low levels of soil organic carbon and total nitrogen, and the low number and relatively low activity of soil microorganisms maintain a relative equilibrium between soil organic carbon and total nitrogen, and when the relative equilibrium is reached, the soil nitrogen content is lagged.

75 Finally, due to the study area's aridity and degraded ecological environment, woody plants in poplar forests and lemon woodland require a high amount of water and nutrients from the soil, 
477 which results in a high correlation between its various soil quality indicators and relatively

478 fragile soil quality. While natural grasslands and farmlands experience a high level of

479 anthropogenic disturbances such as irrigation, animal husbandry, and so on, which has a greater

480 impact on the relationship between their soil quality indicators, abandoned lands experience

481 fewer human-induced and natural disturbances and have sparse surface vegetation, resulting in a

482 low correlation between soil quality indicators.

483

484

485

486

487

488

489

490

491

492

493

494

495

496

497

498

499

The impact of land-use changes on soil quality

The purpose of soil quality evaluation is to gain a thorough understanding of the soil and to reflect changes in soil management to manage and protect it effectively (Rachman et al., 2020). As can be seen from the above results, the soil quality comprehensive scores for the five different land-use types in YongDeng County are ranked as follows: farmland $>$ abandoned farmland $>0>$ natural grassland $>$ lemon woodland $>$ poplar woodland, where a higher comprehensive score indicates a higher degree of soil quality under that land use type, and vice versa. The composite scores of farmland and abandoned farmland were positive, indicating that the soil quality under these vegetation types is higher than the average level, while the composite scores of grassland, lemon woodland, and poplar woodland were negative, indicating belowaverage soil quality.

This result is because the farmland in this area has a certain soil fertilization effect as a result of a series of fine management measures such as rational fertilization and irrigation, which

effectively improves soil fertility and prevents soil degradation, and thus the farmland had the highest soil quality score and was higher than average. Secondly, natural grassland had a lower

500 soil quality score due to the influence of soil salinization in the area as this distresses the soil

501 Furthermore, it affects the vegetation growth directly by reducing the grass plant water uptake respiration, nitrogen cycle, and decomposing functionality of soil microorganisms (Singh, 2016).

502 (osmotic stress) and/or by deteriorating the transpiring leaves (specific ion effects) (Parihar et al., 503 2015), in turn reducing organic input to the soil. However, naturally restored grassland retains 504 some fertility after abandonment, which can help improve soil fertility to some extent (Deru et 505 al., 2018; Li et al., 2021). Finally, compared to grassland, lemon woodland and poplar 506 woodlands extract more nutrients from the soil, lowering soil quality. However, because of the 507 obvious fertility island effects, the soil quality of lemon woodland was higher than that of poplar 508 woodland.

509 As an ecological transition zone separating agricultural areas in eastern China from grassland510 pastoral areas in the west, YongDeng County is a marginal area for traditional cultivation due to 511 its harsh natural conditions, low annual rainfall, and high inter-annual variability. To enhance 512 agricultural and pastoral productivity and ecological conditions, the area's land-use structure 513 should be adjusted. The geographical environment of the sample plots in the study area is quite 514 different, but the principle of adapting measures to local conditions should be followed.

515

\section{Conclusions}


517 The effect of various land-use changes on the physicochemical properties and quality of soil in 518 YongDeng County is evaluated in this study. The study revealed that land-use change has a 519 significant effect on the quality and spatial distribution of soil physicochemical properties. In the 520 study area, the soil quality of farmland that has been finely managed and naturally restored to 521 grassland following abandonment is superior, whereas the soil quality of natural grassland, 522 artificial lemon woodland, and poplar forest land is substandard. The comprehensive analysis 523 demonstrates that conservation tillage and fine management of water-irrigated farmland, as well 524 as the natural conversion of abandoned farmland to grassland, can improve the soil quality of 525 sandy soils, reduce water and soil loss, increase fertility, and gradually improve regional 526 ecological environmental conditions.

527

\section{Acknowledgements}

529

530

531

532

533

534

535

536

537

538

539

540

541

542

543

544

545

546

547

548

549

550

551

552

553

554

555

556

557

558

559

Appreciation goes to the College of Forestry and College of Resources and Environment of Gansu Agricultural University for the tremendous support in the successful execution of this project.

\section{References}

1. Amer, A. M. (2019). Soil moisture adsorption capacity and specific surface area in relation to water vapor pressure in arid and tropical soils. Eurasian Journal of Soil Science, 8(4). https://doi.org/10.18393/ejss.580889

2. Batjes, N. H. (2014). Total carbon and nitrogen in the soils of the world. European Journal of Soil Science, 65(1). https://doi.org/10.1111/ejss.12114_2

3. Biro, K., Pradhan, B., Buchroithner, M., \& Makeschin, F. (2013). Land Use/Land Cover Change Analysis And Its Impact On Soil Properties In The Northern Part Of Gadarif Region, Sudan. Land Degradation and Development, 24(1). https://doi.org/10.1002/ldr.1116

4. Braimoh, A. K., \& Vlek, P. L. G. (2004). The impact of land-cover change on soil properties in northern Ghana. Land Degradation and Development, 15(1). https://doi.org/10.1002/ldr.590

5. Calicioglu, O., Flammini, A., Bracco, S., Bellù, L., \& Sims, R. (2019). The future challenges of food and agriculture: An integrated analysis of trends and solutions. Sustainability (Switzerland), 11(1). https://doi.org/10.3390/su11010222

6. Cao, H., Jia, M., Song, J., Xun, M., Fan, W., \& Yang, H. (2021). Rice-straw mat mulching improves the soil integrated fertility index of apple orchards on cinnamon soil and fluvo-aquic soil. Scientia Horticulturae, 278.

https://doi.org/10.1016/j.scienta.2020.109837

7. Chen, J., He, B., Wang, X., Ma, Y., \& Xi, W. (2013). The effects of Herba Andrographitis hedgerows on soil erodibility and fractal features on sloping cropland in the Three Gorges Reservoir Area. Environmental Science and Pollution Research, 20(10). https://doi.org/10.1007/s11356-013-1704-z

8. Demmel, J., \& Veselić, K. (1992). Jacobi's Method is More Accurate than QR. SIAM Journal on Matrix Analysis and Applications, 13(4). https://doi.org/10.1137/0613074

9. Deng, L., Wang, G. liang, Liu, G. bin, \& Shangguan, Z. ping. (2016). Effects of age and

Peerj reviewing PDF | (2021:07:63271:1:2:NEW 6 Sep 2021) 
560

561

562

563

564

565

566

567

568

569

570

571

572

573

574

575

576

577

578

579

580

581

582

583

584

585

586

587

588

589

590

591

592

593

594

595

596

597

598

599

600

601

602

603

604

605

land-use changes on soil carbon and nitrogen sequestrations following cropland abandonment on the Loess Plateau, China. Ecological Engineering, 90. https://doi.org/10.1016/j.ecoleng.2016.01.086

10. Deru, J. G. C., Bloem, J., de Goede, R., Keidel, H., Kloen, H., Rutgers, M., van den Akker, J., Brussaard, L., \& van Eekeren, N. (2018). Soil ecology and ecosystem services of dairy and semi-natural grasslands on peat. Applied Soil Ecology, 125. https://doi.org/10.1016/j.apsoil.2017.12.011

11. Ding, F., Hu, Y. L., Li, L. J., Li, A., Shi, S., Lian, P. Y., \& Zeng, D. H. (2013). Changes in soil organic carbon and total nitrogen stocks after conversion of meadow to cropland in Northeast China. Plant and Soil, 373(1-2). https://doi.org/10.1007/s11104-013-1827-5

12. Ding, Z., Kheir, A. M. S., Ali, M. G. M., Ali, O. A. M., Abdelaal, A. I. N., Lin, X., Zhou, Z., Wang, B., Liu, B., \& He, Z. (2020). The integrated effect of salinity, organic amendments, phosphorus fertilizers, and deficit irrigation on soil properties, phosphorus fractionation and wheat productivity. Scientific Reports, 10(1). https://doi.org/10.1038/s41598-020-59650-8

13. E. Jobbágy, \& R. Jackson. (2000). The vertical distribution of soil organic carbon and its relation to climate and vegetation. In Ecological Applications (Vol. 10, Issue 2).

14. Evans, R. D., \& Belnap, J. (1999). Long-term consequences of disturbance on nitrogen dynamics in an arid ecosystem. Ecology, 80(1). https://doi.org/10.1890/00129658(1999)080[0150:LTCODO]2.0.CO;2

15. Feng, Q., Zhao, W., Wang, J., Zhang, X., Zhao, M., Zhong, L., Liu, Y., \& Fang, X. (2016). Effects of Different Land-Use Types on Soil Erosion Under Natural Rainfall in the Loess Plateau, China. Pedosphere, 26(2). https://doi.org/10.1016/S10020160(15)60039-X

16. Fiorini, A., Boselli, R., Maris, S. C., Santelli, S., Ardenti, F., Capra, F., \& Tabaglio, V. (2020). May conservation tillage enhance soil $\mathrm{C}$ and $\mathrm{N}$ accumulation without decreasing yield in intensive irrigated croplands? Results from an eight-year maize monoculture. Agriculture, Ecosystems and Environment, 296. https://doi.org/10.1016/j.agee.2020.106926

17. Fornara, D. A., Tilman, D., \& Houlton, B. Z. (2012). Soil carbon sequestration in prairie grasslands increased by chronic nitrogen addition. Ecology, 93(9). https://doi.org/10.1890/12-0292.1

18. Gerschlauer, F., Saiz, G., Schellenberger Costa, D., Kleyer, M., Dannenmann, M., \& Kiese, R. (2019). Stable carbon and nitrogen isotopic composition of leaves, litter, and soils of various ecosystems along an elevational and land-use gradient at Mount Kilimanjaro, Tanzania. Biogeosciences, 16(2). https://doi.org/10.5194/bg-16-409-2019

19. Herbert, E. R., Boon, P., Burgin, A. J., Neubauer, S. C., Franklin, R. B., Ardon, M., Hopfensperger, K. N., Lamers, L. P. M., Gell, P., \& Langley, J. A. (2015). A global perspective on wetland salinization: Ecological consequences of a growing threat to freshwater wetlands. In Ecosphere (Vol. 6, Issue 10). https://doi.org/10.1890/ES1400534.1

20. Jeong, A., \& Dorn, R. I. (2019). Soil erosion from urbanization processes in the Sonoran Desert, Arizona, USA. Land Degradation and Development, 30(2). https://doi.org/10.1002/ldr.3207

21. Khalili Moghadam, B., Jabarifar, M., Bagheri, M., \& Shahbazi, E. (2015). Effects of land use change on soil splash erosion in the semi-arid region of Iran. Geoderma, 241-242. 
606

607

608

609

610

611

612

613

614

615

616

617

618

619

620

621

622

623

624

625

626

627

628

629

630

631

632

633

634

635

636

637

638

639

640

641

642

643

644

645

646

647

648

649

650

651

https://doi.org/10.1016/j.geoderma.2014.11.025

22. Koetlisi, K. A., \& Muchaonyerwa, P. (2019). Evaluation of Soil Amendment with Biochar from Sewage Sludge on Heavy Metal Concentrations in Leachates of Applied Industrial Effluent: A Leaching Column Study. International Journal of Ecology \& Development, 34(4).

23. Kosmas, C., Gerontidis, S., \& Marathianou, M. (2000). The effect of land use change on soils and vegetation over various lithological formations on Lesvos (Greece). Catena, 40(1). https://doi.org/10.1016/S0341-8162(99)00064-8

24. Kumar, S., Kumar, V., Singh, Y. V, Jatav, H. S., Jayant, H., Chattopadhya, A., \& Dhawal, S. K. (2017). Role of Biochar: In agriculture sector its implication and perspective. $14 \sim$ International Journal of Chemical Studies, 5(2).

25. Kyte, R. (2014). Achieving global food security: Building a new food system where nutrition, climate change and sustainability collide. Conference Proceedings. https://doi.org/10.22004/ag.econ.225572

26. Lal, R. (2015). Restoring soil quality to mitigate soil degradation. Sustainability (Switzerland), 7(5). https://doi.org/10.3390/su7055875

27. Lammerts van Bueren, E. T., Struik, P. C., van Eekeren, N., \& Nuijten, E. (2018). Towards resilience through systems-based plant breeding. A review. In Agronomy for Sustainable Development (Vol. 38, Issue 5). https://doi.org/10.1007/s13593-018-0522-6

28. Latifi, N., Vahedifard, F., Ghazanfari, E., \& A. Rashid, A. S. (2018). Sustainable Usage of Calcium Carbide Residue for Stabilization of Clays. Journal of Materials in Civil Engineering, 30(6). https://doi.org/10.1061/(asce)mt.1943-5533.0002313

29. Letters, E., Yu, G., Xiao, J., Hu, S., Polizzotto, M. L., Zhao, F., Little, J. B., FAO, Crowther, T. W., Riggs, C., Lind, E. M., Borer, E. T., Seabloom, E. W., Hobbie, S. E., Wubs, J., Adler, P. B., Firn, J., Gherardi, L., Hagenah, N., ... Survey, B. G. (2019). Cis1124. Global Change Biology, 92(12).

30. Li, Q., Yang, J., Guan, W., Liu, Z., He, G., Zhang, D., \& Liu, X. (2021). Soil fertility evaluation and spatial distribution of grasslands in Qilian Mountains Nature Reserve of eastern Qinghai-Tibetan Plateau. PeerJ, 9. https://doi.org/10.7717/peerj.10986

31. Lu, M., Zhou, X., Luo, Y., Yang, Y., Fang, C., Chen, J., \& Li, B. (2011). Minor stimulation of soil carbon storage by nitrogen addition: A meta-analysis. Agriculture, Ecosystems and Environment, 140(1-2). https://doi.org/10.1016/j.agee.2010.12.010

32. Manpoong, C., \& Tripathi, S. K. (2019). Soil properties under different land use systems of Mizoram, North East India. Journal of Applied and Natural Science, 11(1). https://doi.org/10.31018/jans.v11i1.1999

33. Negasa, D. J. (2020). Effects of Land Use Types on Selected Soil Properties in Central Highlands of Ethiopia. Applied and Environmental Soil Science, 2020. https://doi.org/10.1155/2020/7026929

34. Parihar, P., Singh, S., Singh, R., Singh, V. P., \& Prasad, S. M. (2015). Effect of salinity stress on plants and its tolerance strategies: a review. Environmental Science and Pollution Research, 22(6). https://doi.org/10.1007/s11356-014-3739-1

35. Paz-Ferreiro, J., \& Fu, S. (2016). Biological Indices for Soil Quality Evaluation: Perspectives and Limitations. Land Degradation and Development, 27(1). https://doi.org/10.1002/ldr.2262

36. Rachman, A., Sutono, S., Irawan, I., \& Suastika, I. W. (2020). Indikator Kualitas Tanah pada Lahan Bekas Penambangan. Jurnal Sumberdaya Lahan, 11(1). 
652

653

654

655

656

657

658

659

660

661

662

663

664

665

666

667

668

669

670

671

672

673

674

675

676

677

678

679

680

681

682

683

684

685

686

687

688

689

690

691

692

693

694

695

696

697

https://doi.org/10.21082/jsdl.v11n1.2017.1-10

37. Sáez-Plaza, P., Navas, M. J., Wybraniec, S., Michałowski, T., \& Asuero, A. G. (2013). An Overview of the Kjeldahl Method of Nitrogen Determination. Part II. Sample Preparation, Working Scale, Instrumental Finish, and Quality Control. Critical Reviews in Analytical Chemistry, 43(4). https://doi.org/10.1080/10408347.2012.751787

38. Sahu, G., Rout, P. P., Mohapatra, S., Das, S. P., \& Pradhan, P. P. (2020). Climate Smart Agriculture: A New Approach for Sustainable Intensification. Current Journal of Applied Science and Technology. https://doi.org/10.9734/cjast/2020/v39i2330862

39. Shangguan, W., Dai, Y., García-Gutiérrez, C., \& Yuan, H. (2014). Particle-size distribution models for the conversion of Chinese data to FAO/USDA system. Scientific World Journal, 2014. https://doi.org/10.1155/2014/109310

40. Shekhovtseva, O. G., \& Mal'tseva, I. A. (2015). Physical, chemical, and biological properties of soils in the city of Mariupol, Ukraine. Eurasian Soil Science, 48(12). https://doi.org/10.1134/S1064229315120145

41. Singh, K. (2016). Microbial and Enzyme Activities of Saline and Sodic Soils. Land Degradation and Development, 27(3). https://doi.org/10.1002/ldr.2385

42. Smith, P., House, J. I., Bustamante, M., Sobocká, J., Harper, R., Pan, G., West, P. C., Clark, J. M., Adhya, T., Rumpel, C., Paustian, K., Kuikman, P., Cotrufo, M. F., Elliott, J. A., Mcdowell, R., Griffiths, R. I., Asakawa, S., Bondeau, A., Jain, A. K., ... Pugh, T. A. M. (2016). Global change pressures on soils from land use and management. Global Change Biology, 22(3). https://doi.org/10.1111/gcb.13068

43. Statuto, D., Cillis, G., \& Picuno, P. (2016). Analysis of the effects of agricultural land use change on rural environment and landscape through historical cartography and GIS tools. Journal of Agricultural Engineering, 47(1). https://doi.org/10.4081/jae.2016.468

44. Vidal, R., Ma, Y., \& Sastry, S. S. (2016). Principal component analysis. In Interdisciplinary Applied Mathematics (Vol. 40). https://doi.org/10.1007/978-0-38787811-9 2

45. Weissert, L. F., Salmond, J. A., \& Schwendenmann, L. (2016). Variability of soil organic carbon stocks and soil CO2 efflux across urban land use and soil cover types. Geoderma, 271. https://doi.org/10.1016/j.geoderma.2016.02.014

46. Yang, H., Xiong, H., Chen, X., Wang, Y., \& Zhang, F. (2015). Identifying the influence of urbanization on soil organic matter content and $\mathrm{pH}$ from soil magnetic characteristics. Journal of Arid Land, 7(6). https://doi.org/10.1007/s40333-015-0052-x

47. Yang, L. N., Pan, Z. C., Zhu, W., Wu, E. J., He, D. C., Yuan, X., Qin, Y. Y., Wang, Y., Chen, R. S., Thrall, P. H., Burdon, J. J., Shang, L. P., Sui, Q. J., \& Zhan, J. (2019). Enhanced agricultural sustainability through within-species diversification. Nature Sustainability, 2(1). https://doi.org/10.1038/s41893-018-0201-2

48. Yao, R., Li, H., Yang, J., Chen, Q., Zheng, F., \& Shang, H. (2020). Regulation Effect of Biomass Improved Materials on Migration of Soil Water, Salt and Nitrogen in Saltaffected Soil under Drip Irrigation. Nongye Jixie Xuebao/Transactions of the Chinese Society for Agricultural Machinery, 51(11). https://doi.org/10.6041/j.issn.10001298.2020.11.031

49. Yost, J. L., \& Hartemink, A. E. (2019). Effects of carbon on moisture storage in soils of the Wisconsin Central Sands, USA. European Journal of Soil Science, 70(3). https://doi.org/10.1111/ejss. 12776

50. Yu, Q., Hu, X., Ma, J., Ye, J., Sun, W., Wang, Q., \& Lin, H. (2020). Effects of long-term

PeerJ reviewing PDF | (2021:07:63271:1:2:NEW 6 Sep 2021) 
698

699

700

701

702

703

704

705

706

707

708

709

710

711

712

713

714

715

716

717

718

719

720 organic material applications on soil carbon and nitrogen fractions in paddy fields. Soil and Tillage Research, 196. https://doi.org/10.1016/j.still.2019.104483

51. Zambon, I., Benedetti, A., Ferrara, C., \& Salvati, L. (2018). Soil Matters? A Multivariate Analysis of Socioeconomic Constraints to Urban Expansion in Mediterranean Europe. Ecological Economics, 146. https://doi.org/10.1016/j.ecolecon.2017.10.015

52. Zhang, J., Zhang, M., Huang, S., \& Zha, X. (2021). Assessing spatial variability of soil organic carbon and total nitrogen in eroded hilly region of subtropical China. PLoS ONE, 15(12 December). https://doi.org/10.1371/journal.pone.0244322

53. Zhang, R., Zhao, X., Zhang, C., \& Li, J. (2020). Impact of rapid and intensive land use/land cover change on soil properties in arid regions: A case study of Lanzhou new area, China. Sustainability (Switzerland), 12(21). https://doi.org/10.3390/su12219226

54. Zhang, Yan, Wei, L., Wei, X., Liu, X., \& Shao, M. (2018). Long-term afforestation significantly improves the fertility of abandoned farmland along a soil clay gradient on the Chinese Loess Plateau. Land Degradation and Development, 29(10). https://doi.org/10.1002/ldr.3126

55. Zhang, Yongli, Yu, Z., Shi, Y., Gu, S., \& Zhang, Y. (2019). Effects of supplemental irrigation based on soil water content on water consumption, dry matter and yield of wheat. Chilean Journal of Agricultural Research, 79(2). https://doi.org/10.4067/S071858392019000200190

56. Zucca, C., Canu, A., \& Previtali, F. (2010). Soil degradation by land use change in an agropastoral area in Sardinia (Italy). Catena, 83(1).

https://doi.org/10.1016/j.catena.2010.07.003 
Figure 1

Map of the study area and sampling points

Map of the study area and sampling points

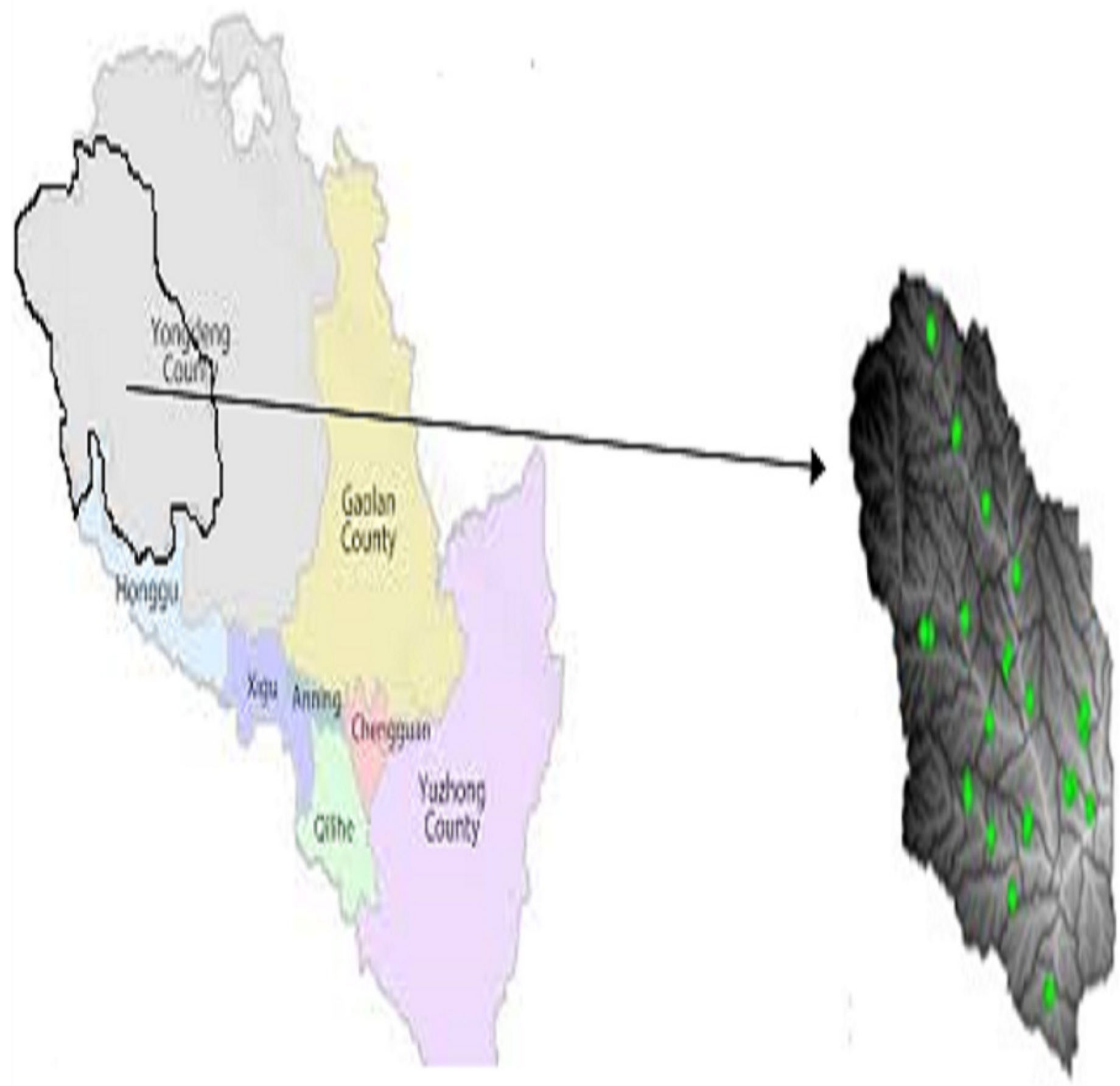


Figure 2

Variation of soil moisture content under different land use types

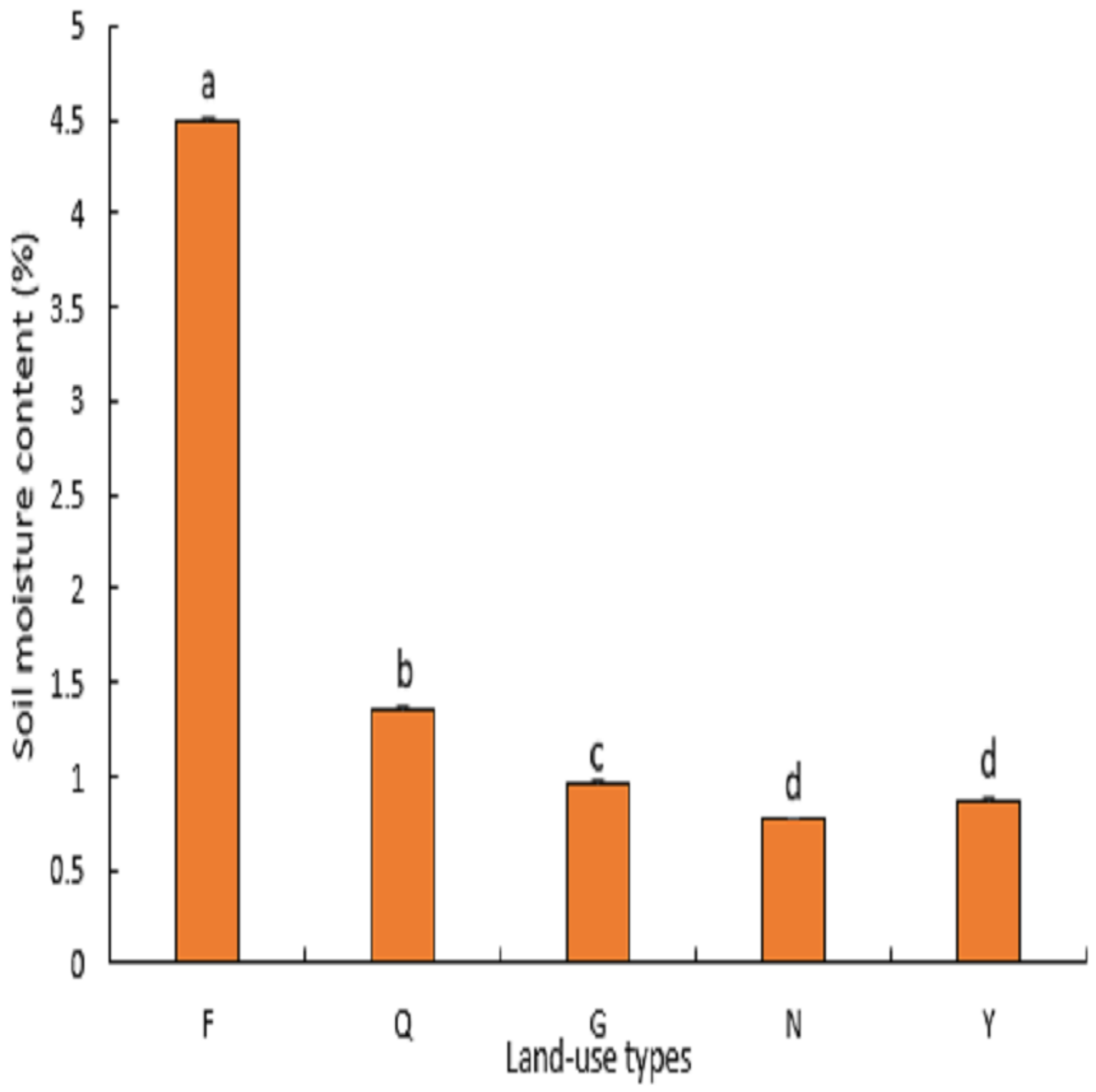


Figure 3

Variation of soil pH under land use types

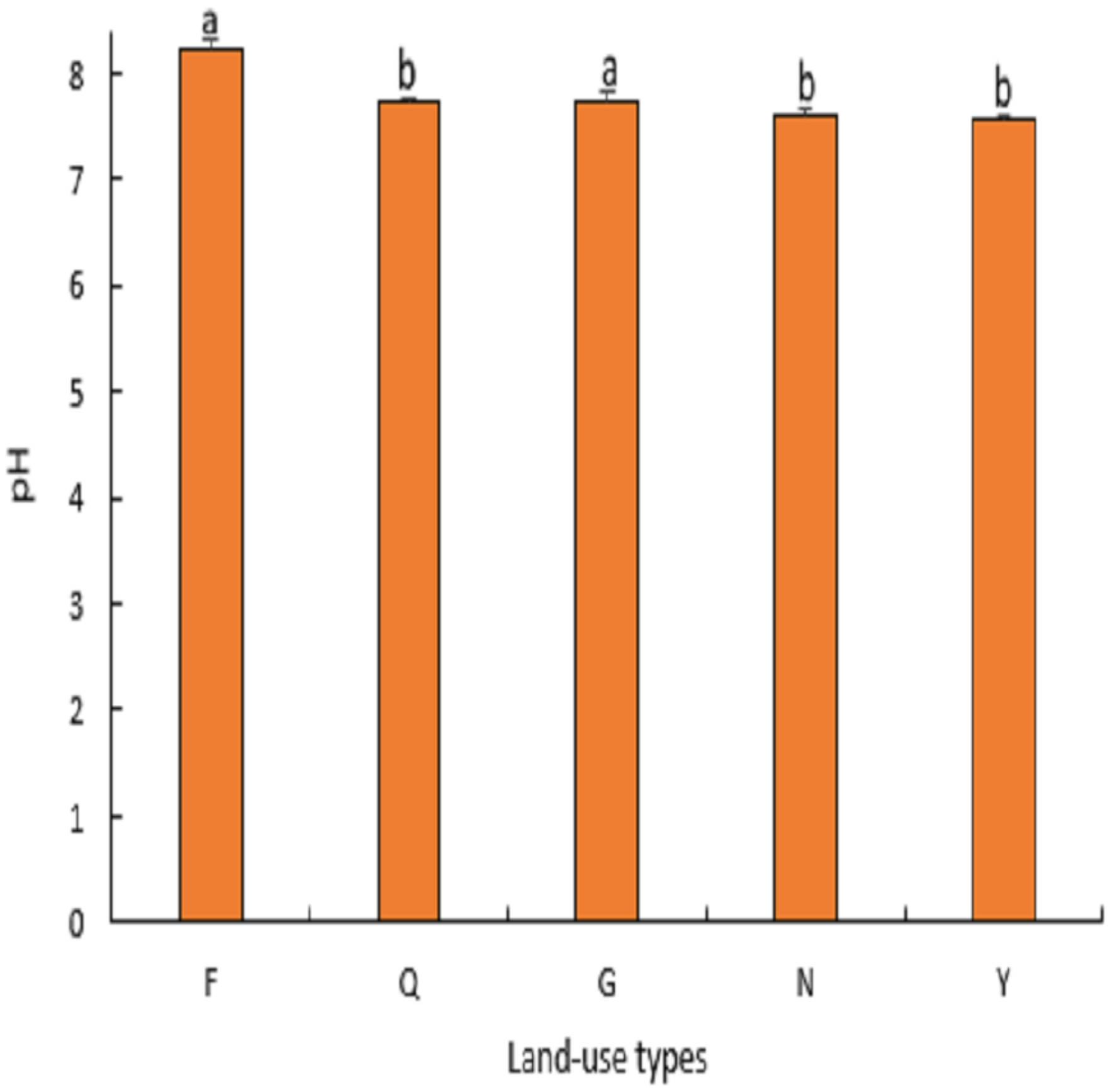


Figure 4

Variation of Electrical conductivity under different land use types

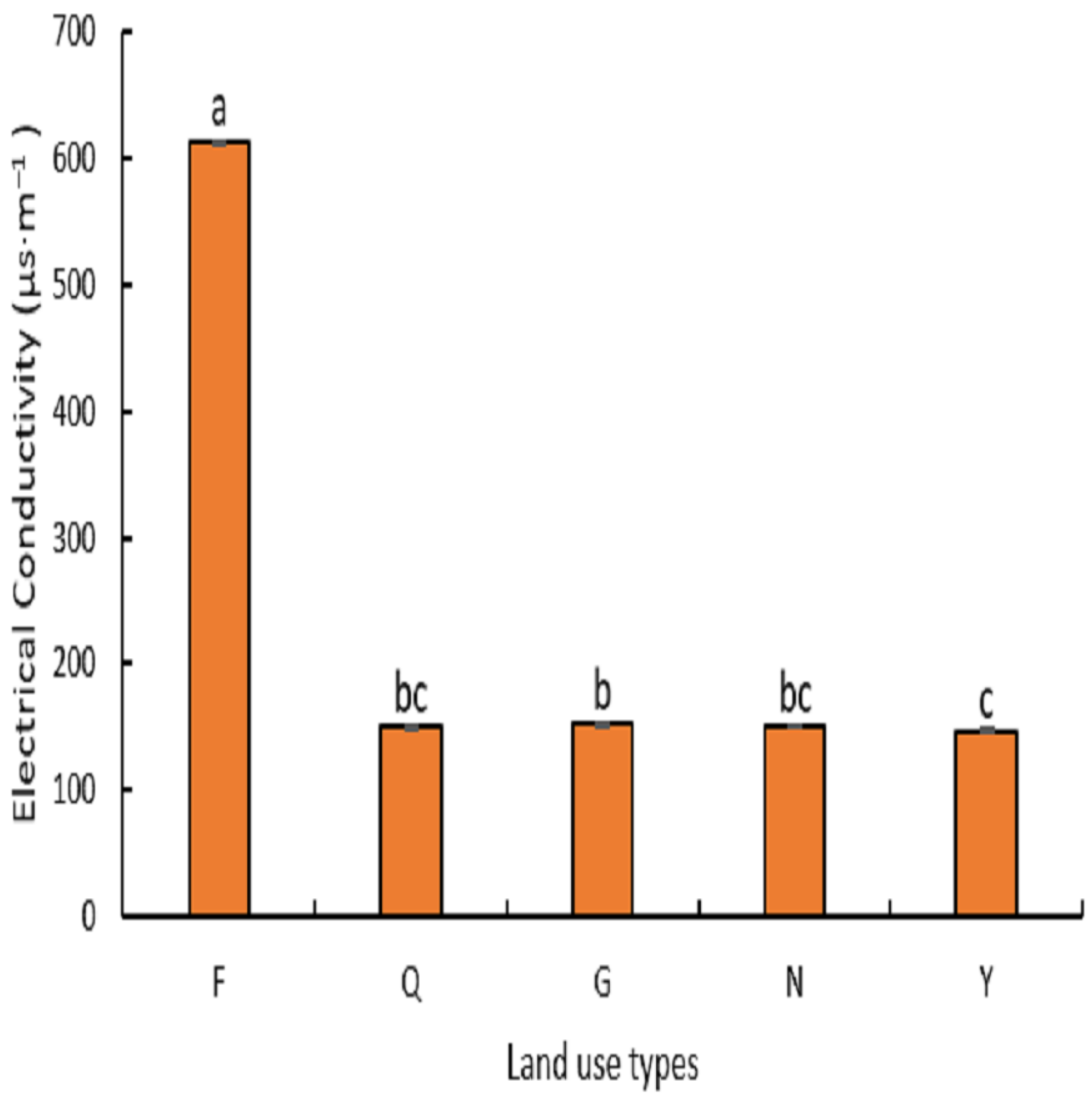


Figure 5

Variation of soil organic carbon under different land use types

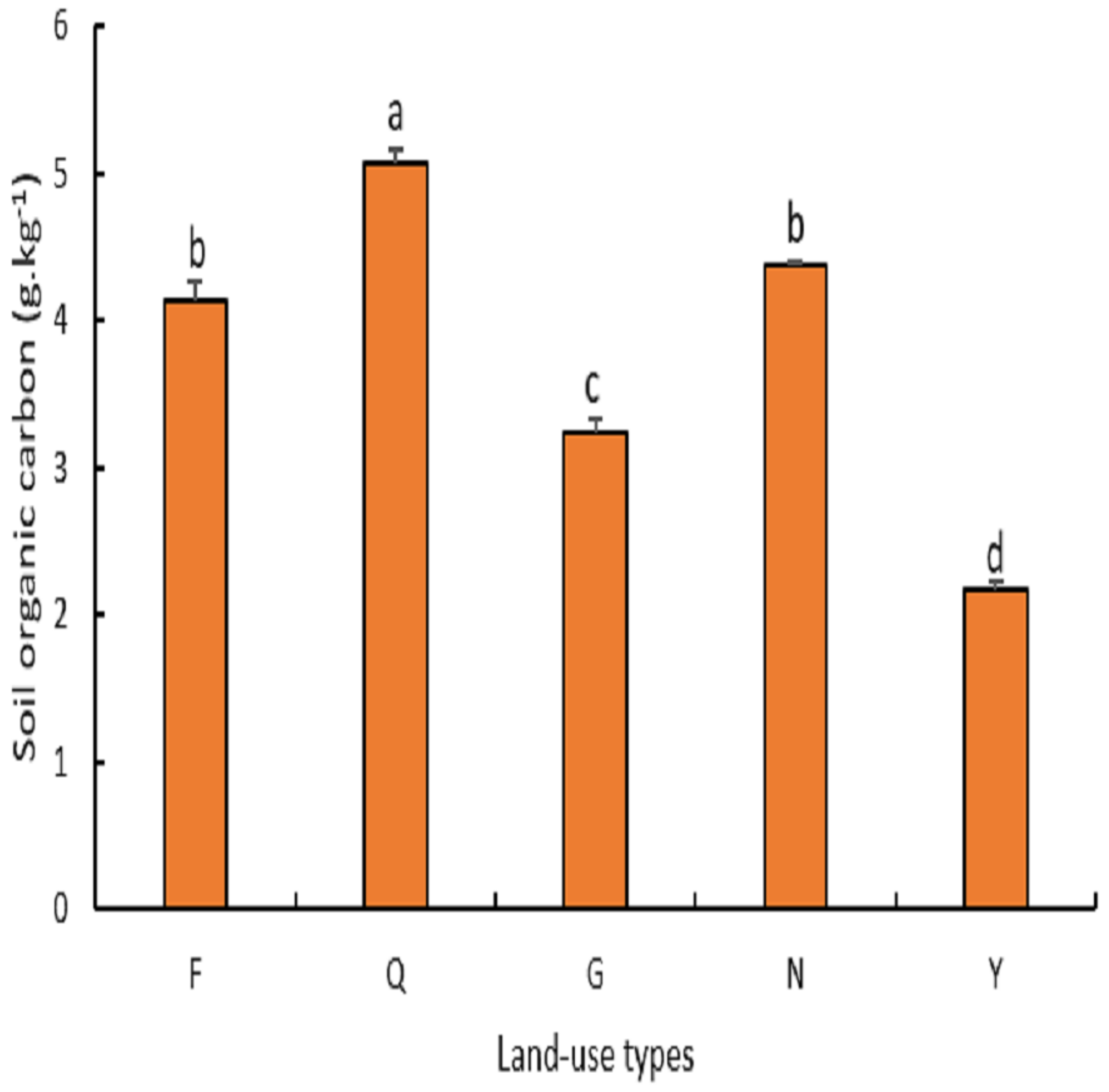


Figure 6

Variation of total nitrogen under different land use types

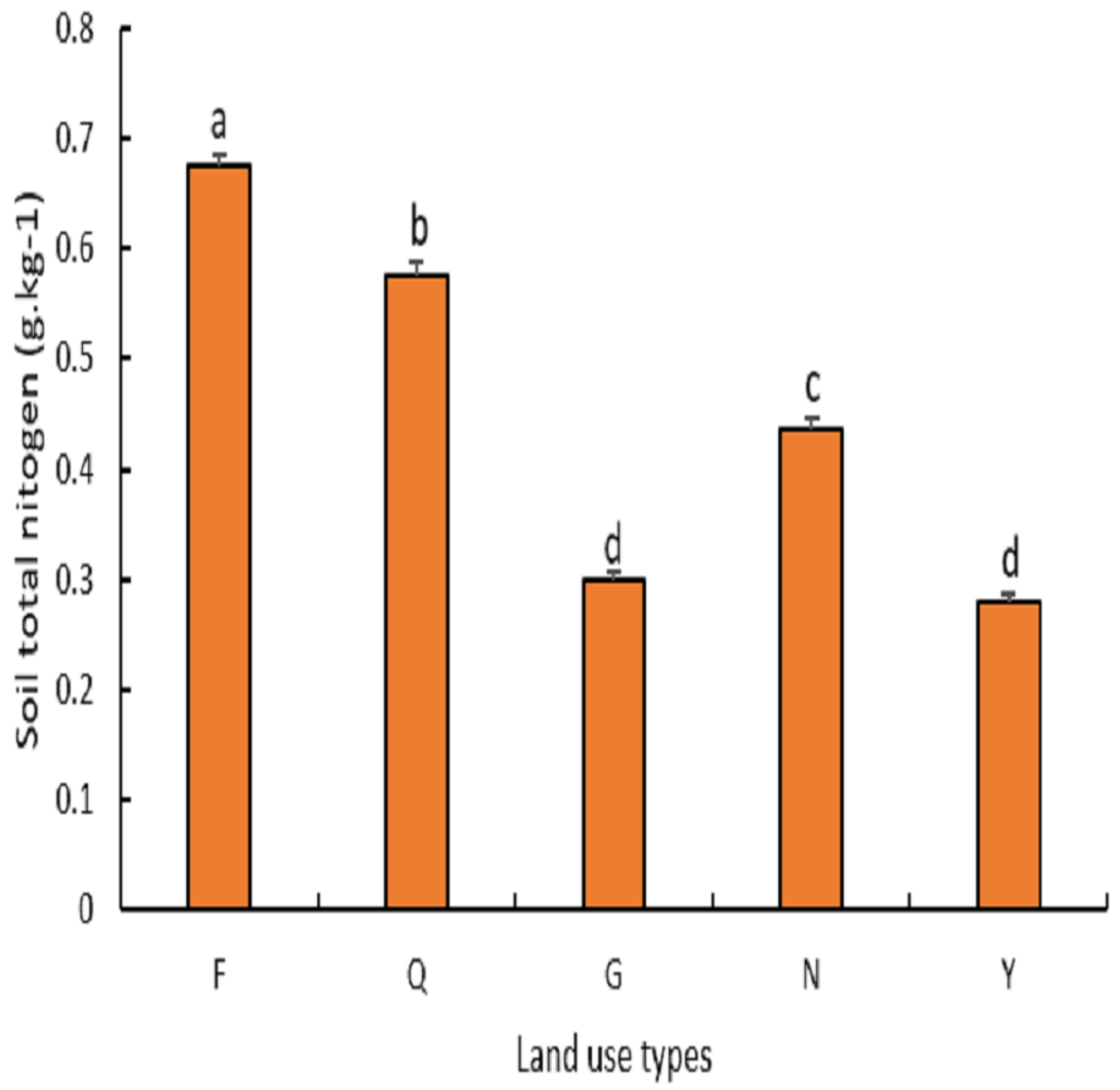




\section{Table 1 (on next page)}

The basic survey of land use types

Note: $\mathrm{F}=$ farmland, $\mathrm{Q}=$ abandoned farmland, $\mathrm{G}=$ natural grassland, $\mathrm{N}=$ artificial lemon woodland, $Y=$ poplar woodland; lowercase letters indicate significant differences between land-use types at $(\mathrm{P}<0.05)$. 
1

\begin{tabular}{cccc}
\hline $\begin{array}{c}\text { Sample } \\
\text { Land }\end{array}$ & $\begin{array}{c}\text { Number of surface } \\
\text { vegetation } \\
\text { species/species }\end{array}$ & $\begin{array}{c}\text { Surface vegetation } \\
\text { average density / } \\
\left(\text { stand } \cdot \mathrm{m}^{-2}\right)\end{array}$ & $\begin{array}{c}\text { Surface vegetation average } \\
\text { height } / \mathrm{cm}\end{array}$ \\
\hline $\mathrm{F}$ & - & - & - \\
$\mathrm{Q}$ & $3.196 \pm 0.008 \mathrm{~b}$ & $71.490 \pm 0.350 \mathrm{~b}$ & $8.420 \pm 0.005 \mathrm{~b}$ \\
$\mathrm{G}$ & $4.396 \pm 0.003 \mathrm{a}$ & $54.546 \pm 0.526 \mathrm{~d}$ & $8.626 \pm 0.008 \mathrm{~b}$ \\
$\mathrm{~N}$ & $3.203 \pm .008 \mathrm{~b}$ & $60.426 \pm 0.396 \mathrm{c}$ & $9.573 \pm 0.331 \mathrm{a}$ \\
$\mathrm{Y}$ & $2.400 \pm 0.214 \mathrm{c}$ & $82.080 \pm 3.188 \mathrm{a}$ & $7.170 \pm 0.006 \mathrm{c}$ \\
\hline
\end{tabular}

2 


\section{Table 2 (on next page)}

Variation of soil particle composition under land use types (\%)

Note: $\mathrm{F}=$ farmland, $\mathrm{Q}=$ abandoned farmland, $\mathrm{G}=$ natural grassland, $\mathrm{N}=$ artificial lemon woodland, $Y=$ poplar woodland; lowercase letters indicate significant differences between land use types $(\mathrm{P}<0.05)$. 
1

\begin{tabular}{ccccc}
\hline $\begin{array}{c}\text { Land use } \\
\text { type }\end{array}$ & $\begin{array}{c}\text { Coarse soil } \\
\text { particles }\end{array}$ & Fine soil particles & $\begin{array}{c}\text { Very fine soil } \\
\text { particles }\end{array}$ & Clay soil particle \\
\hline $\mathrm{F}$ & $18.860 \pm 0.082 \mathrm{~b}$ & $28.870 \pm 0.078 \mathrm{~d}$ & $40.893 \pm 0.133 \mathrm{a}$ & $11.130 \pm 0.236 \mathrm{a}$ \\
$\mathrm{Q}$ & $24.016 \pm 0.170 \mathrm{a}$ & $35.703 \pm 0.574 \mathrm{~b}$ & $33.133 \pm 0.240 \mathrm{c}$ & $6.526 \pm 0.095 \mathrm{c}$ \\
$\mathrm{G}$ & $23.403 \pm 1.171 \mathrm{a}$ & $36.643 \pm 1.124 \mathrm{~b}$ & $32.346 \pm 0.574 \mathrm{c}$ & $6.013 \pm 0.006 \mathrm{~cd}$ \\
$\mathrm{~N}$ & $18.053 \pm 0.114 \mathrm{~b}$ & $33.386 \pm 0.916 \mathrm{c}$ & $38.313 \pm 0.288 \mathrm{~b}$ & $9.323 \pm 0.03512 \mathrm{~b}$ \\
$\mathrm{Y}$ & $16.156 \pm 0.238 \mathrm{c}$ & $46.143 \pm 0.323 \mathrm{a}$ & $32.713 \pm 0.540 \mathrm{c}$ & $4.246 \pm 0.035 \mathrm{e}$ \\
\hline
\end{tabular}

2 


\section{Table 3 (on next page)}

Correlation coefficient of soil physical and chemical properties indexes under land use types

Note: $\mathrm{F}=$ agricultural land, $\mathrm{Q}=$ abandoned farmland land, $\mathrm{G}=$ natural grassland, $\mathrm{N}=$ artificial lemon woodland, $Y=$ poplar woodland; $X_{1}=$ coarse soil particles, $X_{2}=$ fine soil particles, $X_{3}=$ very fine soil particles, $X_{4}=$ clay soil particles, $X_{5}=$ soil water content, $X_{6}=$ soil $\mathrm{pH}, \mathrm{X}_{7}=$ soil electrical conductivity, $\mathrm{X}_{8}=$ soil organic carbon, $\mathrm{X}_{9}=$ total soil nitrogen 


\begin{tabular}{|c|c|c|c|c|c|c|c|c|c|c|}
\hline & & $X_{I}$ & $X_{2}$ & $X_{3}$ & $X_{4}$ & $X_{5}$ & $X_{6}$ & $X_{7}$ & $X_{8}$ & $X_{9}$ \\
\hline \multirow{9}{*}{$\mathrm{F}$} & $X_{I}$ & 1 & & & & & & & & \\
\hline & $X_{2}$ & -0.012 & 1 & & & & & & & \\
\hline & $X_{3}$ & $-0.991 * *$ & 0.021 & 1 & & & & & & \\
\hline & $X_{4}$ & -0.380 & $-0.901 *$ & 0.343 & 1 & & & & & \\
\hline & $X_{5}$ & 0.851 & 0.153 & $-0.905^{*}$ & -0.379 & 1 & & & & \\
\hline & $X_{6}$ & -0.819 & -0.077 & 0.842 & 0.344 & -0.757 & 1 & & & \\
\hline & $X_{7}$ & 0.164 & -0.114 & -0.286 & 0.219 & 0.61 & -0.203 & 1 & & \\
\hline & $X_{8}$ & 0.549 & -0.441 & -0.634 & 0.309 & 0.672 & -0.716 & 0.679 & 1 & \\
\hline & $X_{9}$ & 0.711 & -0.193 & -0.792 & 0.023 & $0.913 *$ & -0.631 & 0.847 & & 1 \\
\hline \multirow{9}{*}{ Q } & $X_{I}$ & 1 & & & & & & & & \\
\hline & $X_{2}$ & 0.433 & 1 & & & & & & & \\
\hline & $X_{3}$ & -0.833 & -0.763 & 1 & & & & & & \\
\hline & $X_{4}$ & -0.626 & -0.531 & 0.414 & 1 & & & & & \\
\hline & $X_{5}$ & -0.578 & 0.184 & 0.211 & 0.348 & 1 & & & & \\
\hline & $X_{6}$ & -0.142 & 0.501 & -0.275 & 0.164 & 0.877 & 1 & & & \\
\hline & $X_{7}$ & 0.371 & 0.351 & -0.656 & 0.267 & 0.317 & 0.671 & 1 & & \\
\hline & $X_{8}$ & 0.265 & -0.67 & 0.087 & 0.246 & -0.741 & -0.721 & -0.05 & 1 & \\
\hline & $X_{9}$ & 0.58 & 0.402 & -0.811 & 0.15 & -0.242 & 0.166 & 0.762 & 0.263 & 1 \\
\hline \multirow{9}{*}{ G } & $X_{I}$ & 1 & & & & & & & & \\
\hline & $X_{2}$ & -0.668 & 1 & & & & & & & \\
\hline & $X_{3}$ & -0.893 & 0.313 & 1 & & & & & & \\
\hline & $X_{4}$ & -0.329 & -0.307 & 0.416 & 1 & & & & & \\
\hline & $X_{5}$ & -0.62 & 0.352 & 0.482 & 0.537 & 1 & & & & \\
\hline & $X_{6}$ & 0.477 & -0.598 & -0.364 & 0.323 & -0.578 & 1 & & & \\
\hline & $X_{7}$ & 0.627 & -0.061 & -0.68 & -0.718 & -0.902 & 0.417 & 1 & & \\
\hline & $X_{8}$ & $0.927^{*}$ & -0.853 & -0.75 & 0.027 & -0.54 & 0.697 & 0.441 & 1 & \\
\hline & $X_{9}$ & 0.702 & -0.391 & -0.58 & -0.537 & -0.993 & 0.598 & 0.92 & 0.617 & 1 \\
\hline \multirow{9}{*}{$\mathrm{N}$} & $X_{I}$ & 1 & & & & & & & & \\
\hline & $X_{2}$ & -0.912 & 1 & & & & & & & \\
\hline & $X_{3}$ & -0.94 & 0.82 & 1 & & & & & & \\
\hline & $X_{4}$ & -0.08 & -0.296 & 0.01 & 1 & & & & & \\
\hline & $X_{5}$ & -0.207 & 0.365 & 0.257 & -0.502 & 1 & & & & \\
\hline & $X_{6}$ & 0.548 & -0.509 & -0.241 & -0.382 & 0.008 & 1 & & & \\
\hline & $X_{7}$ & 0.144 & 0.148 & -0.114 & -0.728 & 0.895 & 0.167 & 1 & & \\
\hline & $X_{8}$ & -0.508 & 0.784 & 0.307 & -0.528 & 0.509 & -0.576 & 0.515 & 1 & \\
\hline & $X_{9}$ & -0.164 & 0.215 & -0.023 & 0.085 & 0.644 & -0.622 & 0.531 & 0.521 & 1 \\
\hline \multirow{9}{*}{$\mathrm{Y}$} & $X_{1}$ & 1 & & & & & & & & \\
\hline & $X_{2}$ & -0.258 & 1 & & & & & & & \\
\hline & $X_{3}$ & -0.942 & -0.068 & 1 & & & & & & \\
\hline & $X_{4}$ & -0.805 & -0.236 & 0.871 & 1 & & & & & \\
\hline & $X_{5}$ & -0.333 & 0.606 & 0.083 & 0.246 & 1 & & & & \\
\hline & $X_{6}$ & 0.263 & 0.753 & -0.483 & -0.758 & 0.027 & 1 & & & \\
\hline & $X_{7}$ & 0.108 & -0.877 & 0.225 & 0.145 & -0.75 & -0.543 & 1 & & \\
\hline & $X_{8}$ & -0.907 & 0.107 & 0.862 & $0.932 *$ & 0.392 & -0.481 & -0.164 & 1 & \\
\hline & $X_{9}$ & -0.942 & -0.039 & 0.967 & $0.948 *$ & 0.208 & -0.543 & 0.082 & $0.959^{* *}$ & 1 \\
\hline
\end{tabular}




\section{Table 4 (on next page)}

Eigenvectors, eigenvalues, contribution rates and cumulative contribution rates of each factor in the principal component analysis

Note: $X_{1}=$ coarse soil particles, $X_{2}=$ fine soil particles, $X_{3}=$ very fine soil particles, $X_{4}=$ clay soil particles, $X_{5}=$ soil water content, $X_{6}=$ soil $\mathrm{pH}, X_{7}=$ soil conductivity, $X_{8}=$ soil organic carbon, $\mathrm{X}_{9}=$ soil total nitrogen. 
1

\begin{tabular}{ccccccccccc}
\hline & 1 & 2 & 3 & 4 & 5 & 6 & 7 & 8 & 9 \\
\hline$X_{1}$ & -0.043 & 0.964 & 0.032 & -0.245 & -0.067 & -0.059 & 0.028 & -0.004 & 0.000 \\
$X_{2}$ & -0.858 & -0.198 & 0.232 & 0.404 & 0.025 & 0.08 & -0.017 & 0.009 & 0.000 \\
$X_{3}$ & 0.686 & -0.667 & -0.200 & -0.085 & 0.099 & -0.162 & 0.018 & -0.040 & 0.000 \\
$X_{4}$ & 0.86 & -0.248 & -0.245 & -0.305 & -0.088 & 0.184 & -0.041 & 0.048 & 0.000 \\
$X_{5}$ & 0.888 & 0.051 & 0.354 & 0.2 & -0.129 & -0.100 & -0.044 & 0.125 & 0.000 \\
$X_{6}$ & 0.678 & 0.155 & 0.556 & -0.076 & 0.444 & 0.048 & -0.021 & -0.016 & 0.000 \\
$X_{7}$ & 0.895 & -0.046 & 0.332 & 0.145 & -0.185 & 0.062 & 0.161 & -0.045 & 0.000 \\
$X_{8}$ & 0.496 & 0.343 & -0.686 & 0.325 & 0.232 & 0.021 & 0.064 & 0.044 & 0.000 \\
$X_{9}$ & 0.885 & 0.297 & -0.113 & 0.272 & -0.124 & 0.011 & -0.127 & -0.100 & 0.000 \\
Eigenvalues & 5.027 & 1.708 & 1.183 & 0.569 & 0.34 & 0.087 & 0.052 & 0.034 & 0.000 \\
Contribution rate & 55.858 & 18.982 & 13.15 & 6.317 & 3.78 & 0.964 & 0.572 & 0.376 & 0.000 \\
Cumulative contribution & 55.858 & 74.841 & 87.99 & 94.307 & 98.087 & 99.051 & 99.624 & 100.000 & 100.000 \\
rate & & & & & & & & &
\end{tabular}




\section{Table 5 (on next page)}

Factor points of principal components and the comprehensive points

Note: $\mathrm{F}=$ farmland, $\mathrm{Q}=$ abandoned farmland, $\mathrm{G}=$ natural grassland, $\mathrm{N}=$ artificial lemon woodland, $Y=$ poplar woodland; $Z_{1}=$ first principal component factor score, $Z_{2}=$ second principal component factor score, $Z_{3}=$ third principal component factor score, $F=$ overall soil quality score 
1

\begin{tabular}{cccccc}
\hline Land use type & $Z_{1}$ & $Z_{2}$ & $Z_{3}$ & $F$ & Ranking \\
\hline $\mathrm{F}$ & 1.725 & -0.255 & 0.777 & 1.017 & 1 \\
$\mathrm{Q}$ & 0.004 & -0.675 & 0.102 & 0.102 & 2 \\
$\mathrm{G}$ & -0.507 & 0.334 & -0.112 & -0.112 & 3 \\
$\mathrm{~N}$ & -0.642 & -0.642 & -1.312 & -0.336 & 4 \\
$\mathrm{Y}$ & -1.147 & -0.765 & 0.876 & -0.671 & 5 \\
\hline
\end{tabular}

2 